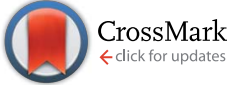

Cite this: Chem. Sci., 2017, 8, 1915

\title{
Responsive hetero-organelle partition conferred fluorogenic sensing of mitochondrial depolarization $\uparrow$
}

\begin{abstract}
Zhongwei Xue, ${ }^{a}$ Hu Zhao, ${ }^{a}$ Jian Liu, ${ }^{a}$ Jiahuai Han ${ }^{b}$ and Shoufa Han*a
Malfunctioning organelles are often difficult to probe with classical organelle-homing sensors owing to disruption of physiological organelle-probe affinity. We herein report the use of a responsive heteroorganelle partition and signal activable probe (RC-TPP) for detecting mitochondrial depolarization, a pathologically relevant event featuring loss of the electrical potentials across the mitochondrial membrane $\left(\Delta \Psi_{\mathrm{m}}\right)$. Partitioned in mitochondria to give blue fluorescence, RC-TPP relocates into lysosomes upon mitochondrial depolarization and exhibits red fluorescence triggered by lysosomal acidity, enabling determination of autophagy relevant mitochondrial depolarization and the chronological sequence of mitochondrial depolarization and lysosomal neutralization in distinct cell death signalling pathways. As an alternative to classic homo-organelle specific molecular systems, this hetero-organelle responsive approach provides a new perspective from which to study dysfunctional organelles.
\end{abstract}

Received 16th September 2016 Accepted 8th November 2016

DOI: $10.1039 / c 6 s c 04158 b$

www.rsc.org/chemicalscience
Recently, detection of mitochondrial depolarization was achieved using a bipolar probe featuring a positively charged hydrophilic group and an environment sensitive fluorophore which exhibits an altered fluorescence lifetime related to membrane polarization. ${ }^{5}$ Herein we report responsive heteroorganelle partition mediated detection of mitochondrial depolarization using RC-TPP, which preferentially accumulates in mitochondria to give blue fluorescence. RC-TPP relocates from depolarized mitochondria into acidic lysosomes to give intense rhodamine fluorescence, allowing a signal-on report of mitochondrial depolarization (Fig. 1).

\section{Results and discussion}

Given the myriad roles of altered $\Delta \Psi_{\mathrm{m}}$ in cell homeostasis and death, ${ }^{2}$ it is imperative to detect mitochondrial depolarization. hydryls once sequestered inside mitochondria. ${ }^{4}$ Although the covalent linkage between dyes and proteins prevents loss of intramitochondrial fluorescence on dissipation of $\Delta \Psi_{\mathrm{m}}$, these probes are incapable of discerning depolarized mitochondria.

${ }^{a}$ State Key Laboratory for Physical Chemistry of Solid Surfaces, Department of Chemical Biology, College of Chemistry and Chemical Engineering, The Key Laboratory for Chemical Biology of Fujian Province, The MOE Key Laboratory of Spectrochemical Analysis \& Instrumentation, Innovation Center for Cell Signalling Network, Xiamen University, Xiamen, 361005, China. E-mail: shoufa@xmu.edu.cn; Tel: +86-0592-2181728

${ }^{b}$ State Key Laboratory of Cellular Stress Biology, Innovation Center for Cell Signalling Network, School of Life Sciences, Xiamen University, Xiamen, 361005, China

$\dagger$ Electronic supplementary information (ESI) available: Biodistribution of RC; cytotoxicity of RC-TPP; and analysis spectra of RC-TPP and RC. See DOI: $10.1039 / \mathrm{c} 6 \mathrm{sc} 04158 \mathrm{~b}$

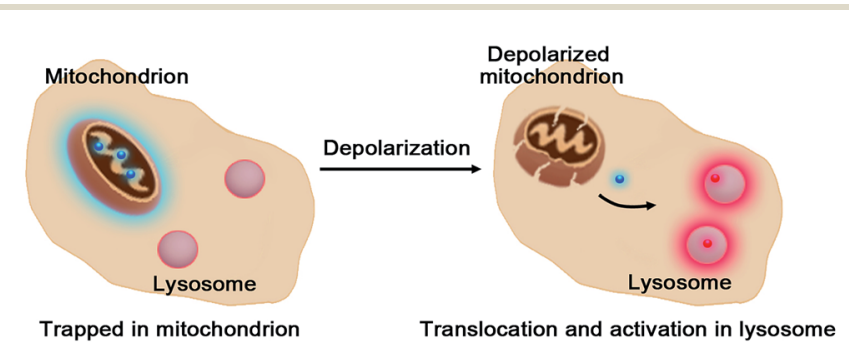

Fig. 1 Schematic for lysosome triggered fluorogenic reporting of mitochondrial depolarization with RC-TPP. Accumulated in mitochondria to give blue fluorescence, RC-TPP relocates from depolarized mitochondria into acidic lysosomes to give "turn-on" red fluorescence. 
As escaping of $\Delta \Psi_{\mathrm{m}}$-responsive dyes from depolarized mitochondria is concomitant with loss of mitochondrion-specific fluorescence, we envisioned that conjugation of mitochondriatargetable agents with a profluorophore that is activable by extra-mitochondrial factors could potentially yield a signal-on assay for mitochondrial depolarization. Rhodamine-lactams, a group of nonfluorescent rhodamine derivatives featuring intramolecular spiro-lactam under alkaline conditions, are prone to proton triggered opening of the lactams to give bright rhodamine fluorescence. ${ }^{6}$ We previously used rhodamine-lactams for imaging of lysosomes. ${ }^{7}$ As such, RC-TPP was constructed to combine a coumarin fluorophore to indicate the sensor's intracellular distribution, a $\Delta \Psi_{\mathrm{m}}$ responsive TPP moiety widely used to ferry various cargoes into mitochondria, ${ }^{8}$ and a rhodamine-lactam profluorophore activable by acidic lysosomes, which are the ubiquitous digestive organelles of mammalian cells (Fig. 2A).

\section{Acidic pH mediated switched-on fluorescence of RC-TPP}

pH titration of RC-TPP shows "always-on" coumarin fluorescence whereas rhodamine fluorescence, negligible at $\mathrm{pH}$ 7.0-9.0, occurred in acidic media and intensified as $\mathrm{pH}$ decreased (pH 6.5-4.5) (Fig. 2B and C), which is consistent with proton mediated opening of the intramolecular lactam (Fig. 2A). Lysosomes are of acidic $\mathrm{pH}$ whereas mitochondria contain

A
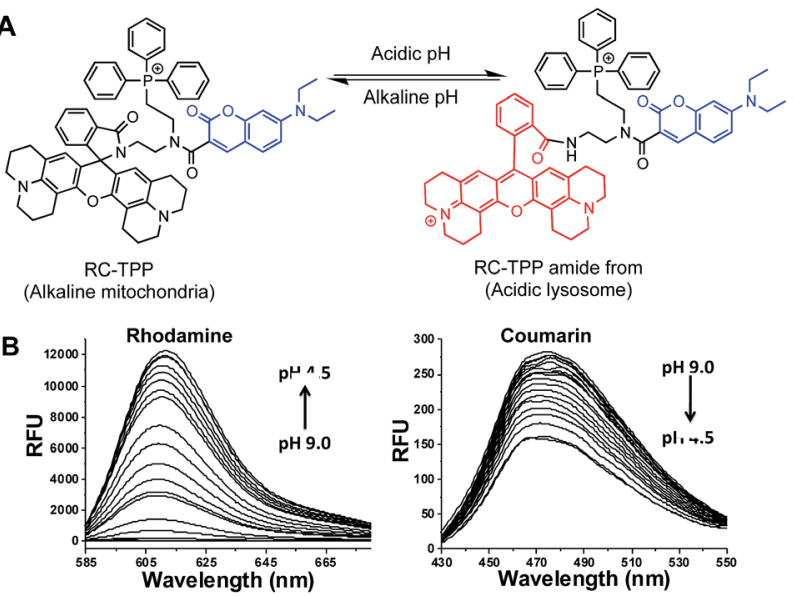

C
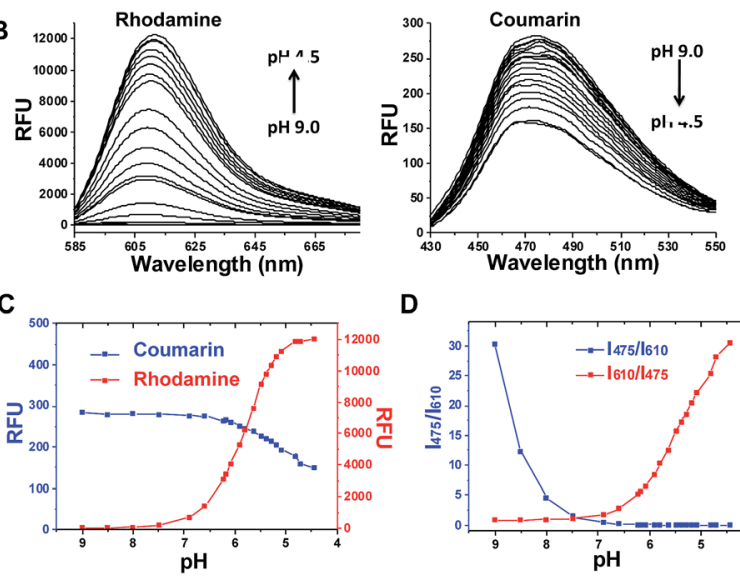

D

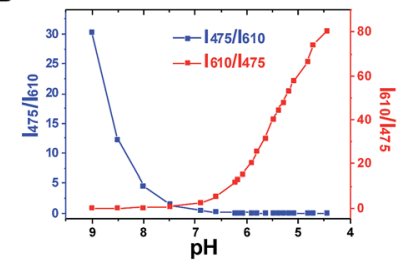

Fig. 2 Acidity triggered rhodamine fluorescence of RC-TPP. (A) Proton mediated fluorogenic opening of the intramolecular spirolactam of RC-TPP to give the amide form of RC-TPP. (B) Fluorescence emission of RC-TPP $(20 \mu \mathrm{M})$ in a buffer of $\mathrm{pH} 4.5-9.0$ ( $\lambda_{\text {ex@4 } 425 \mathrm{~nm} \text { for coumarin and }}$ $\lambda_{\text {ex@585 } \mathrm{nm}}$ for rhodamine). (C) $\mathrm{pH}$ titration curves of RC-TPP $(20 \mu \mathrm{M})$; fluorescence emission of rhodamine $\left(\lambda_{\text {ema615 }} \mathrm{nm}\right)$ and coumarin $\left(\lambda_{\text {eme } 485 \mathrm{~nm}}\right)$ was plotted against buffer $\mathrm{pH}$; (D) $\mathrm{pH}$ dependent fluorescence ratios of rhodamine $\left(I_{615 \mathrm{~nm}}\right)$ to coumarin $\left(I_{475 \mathrm{~nm}}\right)$. alkaline lumen with the $\mathrm{pH}$ maintained by the transmembrane proton gradients. ${ }^{9}$ The ratiometric titration shows distinct blue to red fluorescence patterns of RC-TPP respectively matching $\mathrm{pH}$ windows of lysosomes $(\mathrm{pH}$ 4.5-6.5) and mitochondria ( pH 8.0) (Fig. 2D).

\section{Accumulation of RC-TPP in polarized mitochondria}

RC-TPP was evaluated for its ability to target mitochondria. HeLa cells stained with RC-TPP $(1 \mu \mathrm{M})$ display negligible red fluorescence and strong blue fluorescence colocalized with Mitrotracker Green specific for mitochondria (Fig. 3A; ESI, Fig. S1 $\dagger$ ). Cells that are stained with an elevated concentration of RC-TPP ( $3 \mu \mathrm{M})$ exhibit sparsely punctate rhodamine signals eclipsing lysosomes bearing Lamp2-GFP (GFP-tagged lysosome associated membrane protein 2) (Fig. 3B). These results show that RC-TPP has a high tendency to be partitioned in mitochondria over lysosomes, and is prone to lysosome activation to give red fluorescence. We next probed the structural factor that leads to accumulation of RC-TPP in mitochondria. Rhodamine-

A

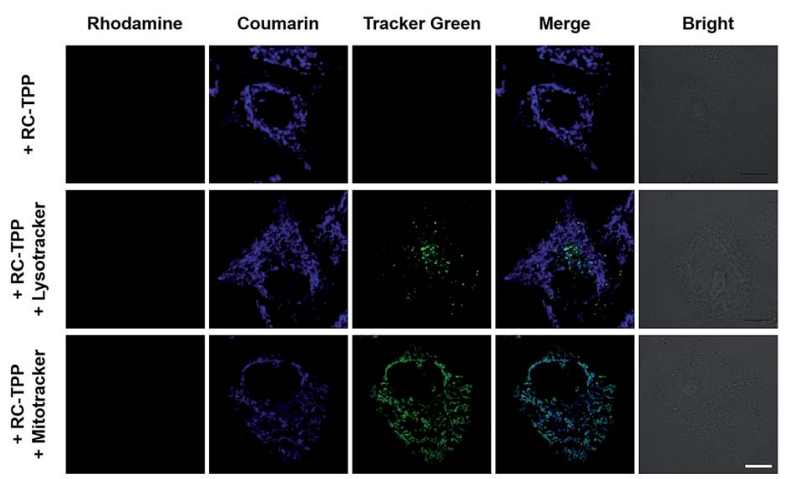

B
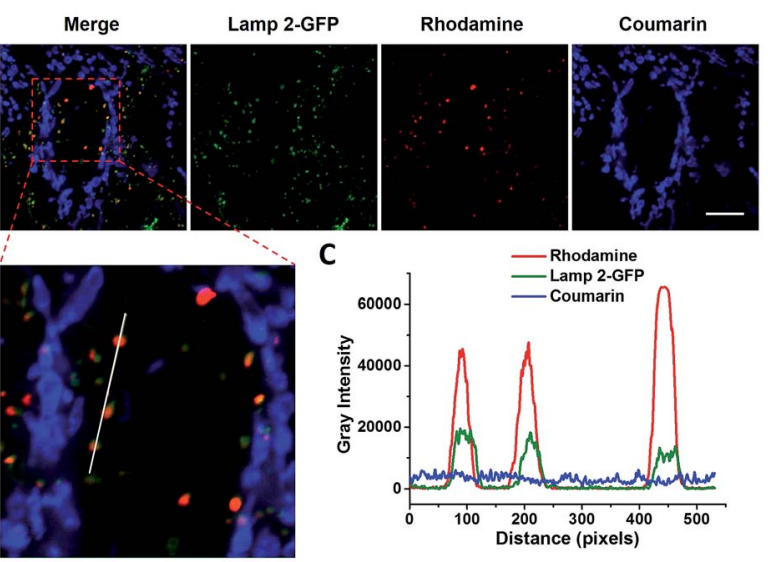

Fig. 3 (A) Partition of blue-emissive RC-TPP in mitochondria. Confocal microscopic images of HeLa cells co-stained with RC-TPP $(1 \mu \mathrm{M})$ and Lysotracker green $(2 \mu \mathrm{M})$ or Mitotracker green $(1 \mu \mathrm{M})$. Colocalization of coumarin with green fluorescence is shown in cyan. (B) Lysosome-specific rhodamine fluorescence of RC-TPP in Lamp2-GFP ${ }^{+}$HeLa cells stained with RC-TPP $(3 \mu M)$. Scale bar: $10 \mu \mathrm{m}$. (C) Plots of fluorescence of coumarin, rhodamine, and GFP were measured along the line shown in the zoomed-in image. Scans taken through the indicated line reveal colocalization of rhodamine fluorescence with Lamp2-GFP. 
coumarin (RC), lacking the TPP moiety, is exclusively located in lysosomes (ESI, Fig. S2†), confirming the critical role of the TPP moiety in mitochondrial partition of RC-TPP.

\section{Mitochondrial $\Delta \Psi_{\mathrm{m}}$ mediated lysosomal partition of RC-TPP}

To elucidate the impacts of $\Delta \Psi_{\mathrm{m}}$ on the subcellular distribution of RC-TPP, HeLa cells expressing Tom20-GFP were analyzed for lysosomal activation of RC-TPP in response to carbonyl cyanide $m$-chlorophenylhydrazone (CCCP), a protonophore used to decrease $\Delta \Psi_{\mathrm{m}} \cdot{ }^{10}$ In contrast with Mitotrackers relying on $\Delta \Psi_{\mathrm{m}}$, Tom20 is a constitutive protein of mitochondria, allowing staging of mitochondria by Tom20-GFP irrespective of $\Delta \Psi_{\mathrm{m}}$. As expected, RC-TPP predominantly resides in mitochondria of control cells whereas CCCP-treated cells exhibit attenuated mitochondrial coumarin fluorescence and dramatically elevated rhodamine signals in a dose dependent manner (Fig. 4; ESI, Fig. S3†), showing relocation of RC-TPP from depolarized mitochondria to lysosomes.

To ascertain the dependence of rhodamine fluorescence of RC-TPP on lysosomal acidity, HeLa cells were probed with RC-TPP in the presence of bafilomycin A1 (BFA), which inhibits vacuolar ATPase-H1 pump and neutralizes lysosomes. ${ }^{11}$ The lack of rhodamine fluorescence in BFA-treated cells proves lysosomal acidity triggered rhodamine fluorescence of RC-TPP in live cells (Fig. 4, ESI, Fig. S4†). The demonstrated translocation of RC-TPP into lysosomes is ascribed to loss of affinity of TPP to mitochondria upon depolarization, and protonation of the rhodamine-lactam by lysosomal acidity and possibly the contribution of the tendency of high molecular weight dyes to accumulate in lysosomes. ${ }^{12}$ Taken together, these data clearly evidence $\Delta \Psi_{\mathrm{m}}$ mediated intra-partition of RC-TPP between mitochondria and lysosomes, and lysosomal acidity mediated activation of RC-TPP upon mitochondrial depolarization.

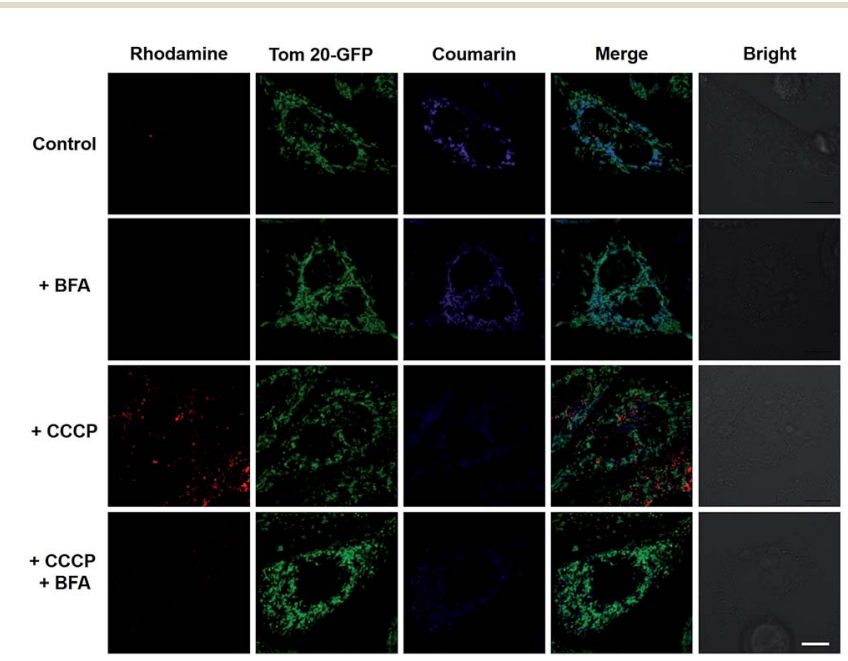

Fig. 4 Mitochondrial depolarization mediated relocation of mitochondrial RC-TPP into lysosomes and the ensuing lysosomal acidity triggered rhodamine fluorescence. RC-TPP-loaded Tom20-GFP ${ }^{+}$ HeLa cells were treated without or with CCCP $(20 \mu \mathrm{M})$ in the presence or absence of BFA (200 nM). Colocalization of Tom20-GFP (in green) and mitochondrial RC-TPP (in blue) is shown in cyan. Scale bar: $10 \mu \mathrm{m}$.
Fluorogenic sensing of autophagy-associated mitochondrial depolarization with RC-TPP

Mitochondrial depolarization correlates with autophagy, a catabolic mechanism mediating cell degradation of unnecessary or dysfunctional cellular components in response to diverse cues such as starvation. ${ }^{13}$ Cells cultivated in Hanks' balanced salt solution (HBSS) free of amino acids display dramatically enhanced rhodamine fluorescence (Fig. 5), which is consistent with nutrient starvation induced mitochondrial depolarization. ${ }^{13}$ Compared with red signal-free control cells or cells treated with apoptosis-inducing staurosporine (STS), there is moderate rhodamine fluorescence induced by the autophagy inducers rotenone or rapamycin (Fig. 4), ${ }^{\mathbf{1 4}}$ demonstrating the utility of RC-TPP in distinguishing the efficacy of autophagy inducers. Flow cytometry analysis confirms enhanced rhodamine fluorescence in CCCP- or HBSS-treated cells, and reveals the synergistic effects of CCCP and HBSS on mitochondrial depolarization (Fig. 6), proving the usefulness of RC-TPP for fluorogenic sensing of mitochondrial depolarization induced by distinct biochemical cues.

Historically, distinct methods have been developed to detect autophagy using GFP-tagged LC-3, ${ }^{15} \mathrm{pH}$-reporting proteins ${ }^{16}$ or dyes covalently immobilized to mitochondria. ${ }^{17}$ Complementing these approaches, our method focuses on the analysis of mitochondrial depolarization, a vital event preceding autophagy, using a small molecular probe prone to $\Delta \Psi_{\mathrm{m}}$ mediated partition between mitochondria and lysosomes.

\section{Analysis of mitochondrial depolarization during apoptosis and necrosis}

Dying cells undergo mitochondrial depolarization and loss of lysosomal acidity owing to membrane permeabilization. ${ }^{18}$ As distinct cell death modalities, apoptosis occurs under physiological conditions and is critical for cell number homeostasis whereas necrosis triggered by external factors leads to
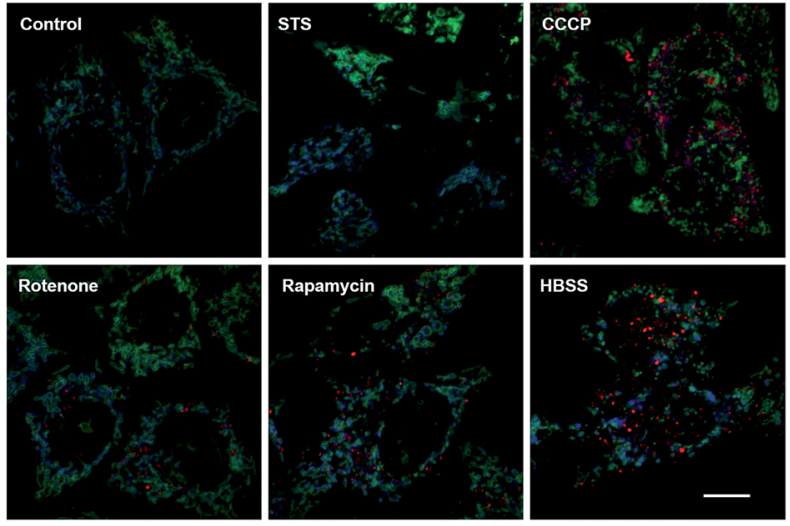

Fig. 5 Confocal microscopic imaging of mitochondrial depolarization with RC-TPP. Tom20-GFP ${ }^{+}$HeLa cells stained with RC-TPP $(2 \mu \mathrm{M})$ were cultivated in glucose-containing HBSS free of amino acids to starve the cells, or in DMEM spiked with rapamycin, rotenone, STS, or CCCP before analysis. Colocalization of RC-TPP with Tom20-GFP is shown in cyan. Scale bar: $10 \mu \mathrm{m}$. 

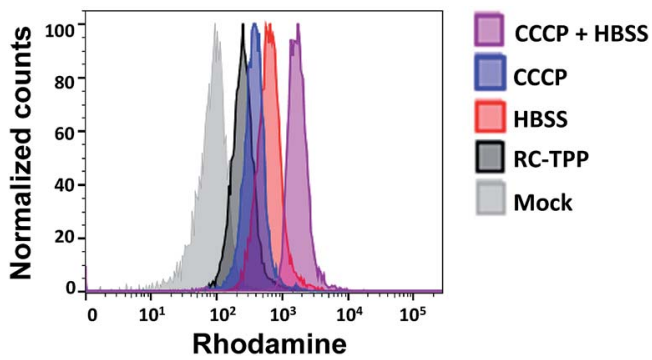

Fig. 6 Flow cytometric analysis of mitochondrial depolarization with RC-TPP. HeLa cells stained with RC-TPP $(2 \mu \mathrm{M})$ were cultivated in HBSS, CCCP-spiked DMEM, or CCCP-spiked HBSS for $4 \mathrm{~h}$ prior to flow cytometric analysis of intracellular rhodamine fluorescence. Mock represents RC-TPP-free cells.
A

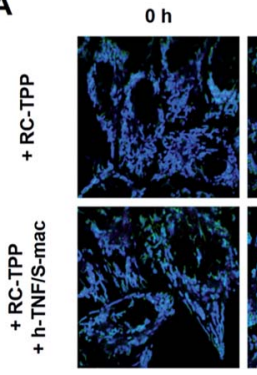

B

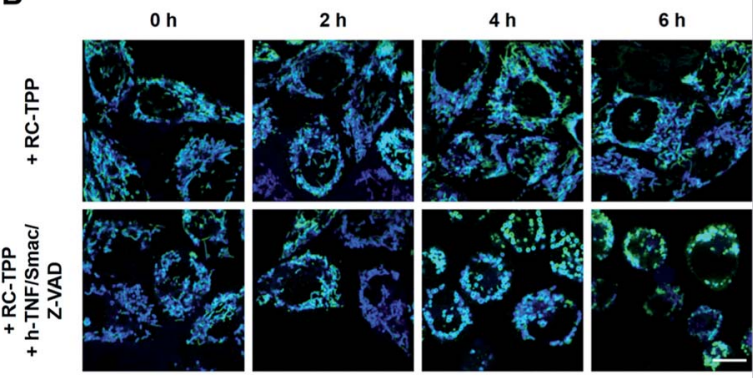

Fig. 7 Time course imaging of cell death associated mitochondrial depolarization and lysosomal neutralization with RC-TPP. (A) Tom20$\mathrm{GFP}^{+} \mathrm{HeLa}$ cells were stained with RC-TPP $(2 \mu \mathrm{M})$ and then cultured for $0-3.5 \mathrm{~h}$ in DMEM spiked with or without human TNF- $\alpha / \mathrm{Smac}$ mimetic to initiate apoptosis. (B) hRIP3 ${ }^{+} / \mathrm{Tom}^{20}$-GFP ${ }^{+}$HeLa cells were stained with RC-TPP $(2 \mu \mathrm{M})$ and then cultured for $0-6 \mathrm{~h}$ in DMEM spiked with or without human TNF- $\alpha /$ smac mimetic/Z-VAD to initiate necroptosis. The cells were imaged by confocal fluorescence microscopy. Overlay of coumarin fluorescence and GFP signals reveals colocalization shown in cyan. The punctate rhodamine signals are indicated by the arrows.

inflammatory responses. ${ }^{19}$ To date, the chronological order of mitochondrial depolarization and lysosomal neutralization during cell death has been undefined.

Tom 20-GFP ${ }^{+}$HeLa cells stained with RC-TPP were treated with human Tumor Necrosis Factor- $\alpha$ (TNF) and Smac to trigger apoptosis. HeLa cells lack the endogenous receptor-interacting protein 3 (RIP3), a mediator which is critical for necrosis. Hence

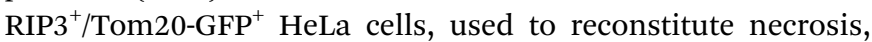
were loaded with RC-TPP and then treated with TNF, Smac and
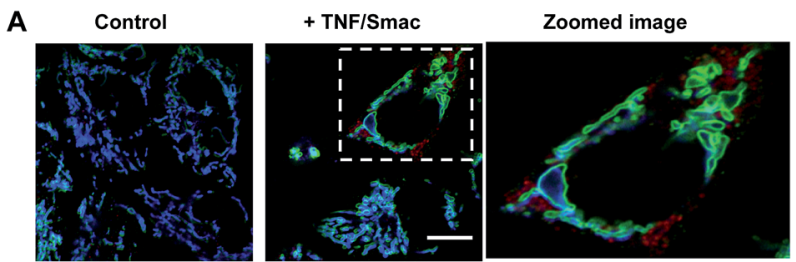

B
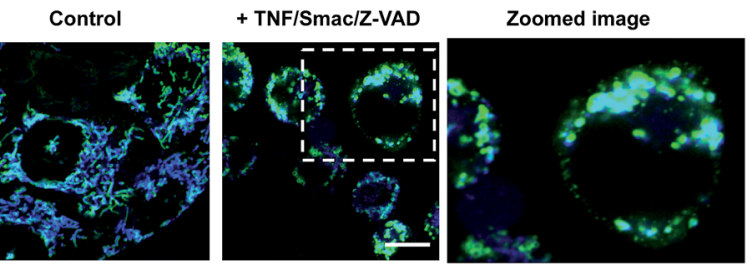

Fig. 8 Imaging of cell death associated mitochondrial depolarization. (A) Tom20-GFP ${ }^{+}$HeLa cells stained with RC-TPP $(2 \mu \mathrm{M})$ were treated with TNF/Smac for $3.5 \mathrm{~h}$ to initiate apoptosis. (B) RIP3 $/$ Tom20-GFP ${ }^{+}$ HeLa cells stained with RC-TPP $(2 \mu \mathrm{M})$ were cultured for $6 \mathrm{~h}$ with TNF/Smac/Z-VAD to trigger necroptosis. Colocalized coumarin and GFP is shown in cyan. Scale bars: $10 \mu \mathrm{m}$.

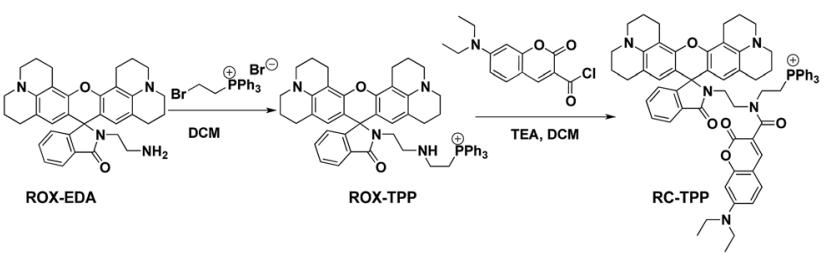

Scheme 1 Synthetic route for RC-TPP.

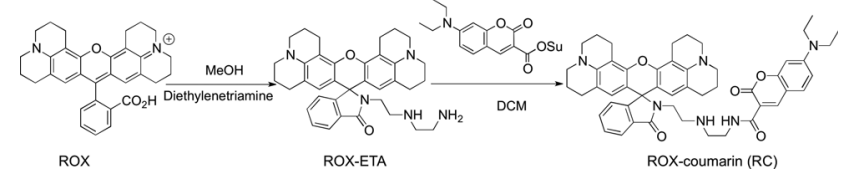

Scheme 2 Synthetic route for RC

Z-VAD to trigger necroptosis, which is a programmed form of necrosis. ${ }^{20}$ Time course imaging reveals subsided localization of RC-TPP in mitochondria in both cell populations, whereas punctate rhodamine signals occurred in apoptotic cells over necroptotic cells (Fig. 7 and 8). Given the dependence of rhodamine fluorescence on lysosomal acidity and translocation of RC-TPP from mitochondria into lysosomes, these results suggest that mitochondrial depolarization precedes lysosome membrane permeabilization in apoptosis, but the succession is swapped during necroptosis.

\section{Conclusions}

RC-TPP was developed for signal-on sensing of mitochondrial depolarization via lysosomal acidity activated fluorescence. RC-TPP, accumulated in mitochondria to exhibit blue fluorescence, relocates to acidic lysosomes to give rhodamine fluorescence upon mitochondrial depolarization, enabling 
detection of mitochondrial depolarization during autophagy and determination of the chronological sequence of mitochondrial depolarization and lysosomal neutralization during distinct cell death pathways. Abnormal organelles are manifested in diverse pathological conditions. ${ }^{21}$ Defining dysfunctional organelles with classic sensors is challenging owing to frequent loss of physiological organelle-probe affinity. Complementing mono-organelle targeting approaches, ${ }^{22}$ the heteroorganelle responsive approach offers a new tool to study malfunctioning organelles.

\section{Experimental procedure}

\section{Materials and methods}

Lysotracker green DND-26 and Mitotracker green were purchased from Invitrogen. Bafilomycin A1 was purchased from Selleck. Rotenone and carbonyl cyanide $m$-chlorophenylhydrazone (CCCP), human tumor necrosis factor- $\alpha$, Smac mimetic, and benzyloxycarbonyl-Val-Ala-DL-Asp $(O$-methyl)fluoromethyl-ketone (Z-VAD-FMK) were obtained from Sigma. All other chemicals were obtained from Alfa-Aesar unless specified.

Cell culturing and overexpression. HeLa, HEK293T, and L929 cells were obtained from American Type Culture Collection (ATCC). Transient transfection of 293T cells was performed using a calcium phosphate method. Lentiviral infection was used for stable expression. Recombinant lentiviruses were packaged in 293T cells in the presence of helper plasmids (pMDLg, pRSV-REWV and pVSV-G) using a calcium phosphate precipitation method. The transfected cells were cultured for $48 \mathrm{~h}$ and the viruses were collected for infection. All cells were maintained in Dulbecco's modified Eagle's medium (DMEM), supplemented with $10 \%$ fetal bovine serum, $2 \mathrm{mM}$ L-glutamine, $100 \mathrm{IU}$ penicillin, and $100 \mathrm{mg} \mathrm{ml}^{-1}$ streptomycin at $37^{\circ} \mathrm{C}$ in a humidified incubator containing $5 \% \mathrm{CO}_{2}$. Full-length cDNA of Tom 20 was cloned into BamHI and XhoI sites of the lentiviral vector pBOB-GFP using the Exo III-assisted ligase-free cloning method as described. ${ }^{23}$ All plasmids were verified by DNA sequencing. For lentivirus production, HEK293T cells were transfected by the calcium phosphate precipitation method. The virus-containing medium was harvested $36-48 \mathrm{~h}$ later and was added to HeLa and RIP3 ${ }^{+}$HeLa cells.

Fluorescence spectra and confocal fluorescence imaging. The fluorescence spectra of RC-TPP were performed on a Spectra Max M5. Confocal microscopic imaging was performed on a Zeiss LSM 780 using the following filters: $\lambda_{\text {ex@ } 905 \mathrm{~nm}}$ and $\lambda_{\text {em@415-491 nm }}$ for coumarin, $\lambda_{\text {ex@488 }} \mathrm{nm}$ and $\lambda_{\text {em@490-553 }} \mathrm{nm}$ for Lysotracker green, Mitotracker green and GFP, and $\lambda_{\text {ex@565 }} \mathrm{nm}$ and $\lambda_{\text {em@593-735 } \mathrm{nm}}$ for rhodamine. Images of the fluorescence of RC-TPP and Lysotracker green in cells were merged using Photoshop CS6. Quantitative imaging analysis was carried out on unprocessed images using ImageJ software. Graphs were generated using GraphPad Prism5 and Origin 8.0 software.

Synthesis of RC-TPP. ROX-EDA $(2.13 \mathrm{~g}, 4 \mathrm{mmol})^{6 a}$ and (2-bromoethyl)-triphenylphosphonium bromide (1.79 g, $4 \mathrm{mmol})$ were dissolved in dichloromethane (DCM) $(40 \mathrm{ml})$ followed by addition of aqueous potassium carbonate solution
$(20 \mathrm{ml})$. The reaction solution was stirred for $2 \mathrm{~h}$, diluted with DCM $(40 \mathrm{ml})$, and then washed with brine $(40 \mathrm{ml})$. The organic solution was dried over anhydrous $\mathrm{Na}_{2} \mathrm{SO}_{4}$. After evaporation of the solvent, ROX-TPP was obtained as an off-white solid in quantitative yield $(3.28 \mathrm{~g}) .{ }^{1} \mathrm{H}-\mathrm{NMR}(500 \mathrm{MHz}, \mathrm{DMSO}) \delta: 7.85$ (dt, $J=7.4,5.5 \mathrm{~Hz}, 3 \mathrm{H}), 7.78-7.68(\mathrm{~m}, 13 \mathrm{H}), 7.49-7.43(\mathrm{~m}, 2 \mathrm{H})$, 6.97-6.92 (m, 1H), $5.88(\mathrm{~s}, 2 \mathrm{H}), 3.57(\mathrm{dt}, J=12.9,6.5 \mathrm{~Hz}, 2 \mathrm{H})$, $3.09(\mathrm{t}, J=5.4 \mathrm{~Hz}, 4 \mathrm{H}), 3.03(\mathrm{t}, J=5.3 \mathrm{~Hz}, 4 \mathrm{H}), 2.86(\mathrm{t}, J=6.7 \mathrm{~Hz}$, $2 \mathrm{H}), 2.83-2.72(\mathrm{~m}, 4 \mathrm{H}), 2.63-2.53(\mathrm{~m}, 2 \mathrm{H}), 2.44-2.30(\mathrm{~m}, 4 \mathrm{H})$, $2.04(\mathrm{t}, 2 \mathrm{H}), 1.97-1.85(\mathrm{~m}, 4 \mathrm{H})$, and $1.69(\mathrm{pd}, J=12.8,6.4 \mathrm{~Hz}$, $4 \mathrm{H}) .{ }^{13} \mathrm{C}-\mathrm{NMR}$ (126 MHz, DMSO) $\delta: 167.18,153.62,147.44$, 143.23, 134.52, 133.55, 133.47, 132.56, 130.08, 129.97, 129.87, 128.04, 123.67, 123.51, 122.18, 119.42, 118.74, 116.86, 106.91, $105.13,64.64,49.08,48.62,46.16,41.77,26.56,21.39,20.80$, and 20.70. MS $\left(\mathrm{C}_{54} \mathrm{H}_{54} \mathrm{~N}_{4} \mathrm{O}_{2} \mathrm{P}^{+}\right)$: calculated $\left(\mathrm{MH}^{+}\right)$: 821.4, found: 821.2 (Scheme 1).

7-Diethylamino-4-carboxy-coumarin $(2.6 \mathrm{~g}, 10.0 \mathrm{mmol})$ was dissolved in anhydrous DCM $(40 \mathrm{ml})$ followed by addition of oxalyl chloride $(2.52 \mathrm{~g}, 20.00 \mathrm{mmol})$ and a drop of $N, N$-dimethylformamide. The mixture was stirred at RT for $2 \mathrm{~h}$ and then evaporated to remove excess oxalyl chloride. The residue was dissolved in anhydrous DCM, and then added dropwise to the solution of ROX-TPP $(0.821 \mathrm{~g}, 1 \mathrm{mmol})$ in anhydrous DCM spiked with triethylamine $(1 \mathrm{ml})$. The mixture was stirred at RT for $1 \mathrm{~h}$ and then evaporated to remove the solvent. The residue was purified by silica gel column chromatography using DCM/MeOH/TEA (20:1:1, v/v/v) as the eluent. RC-TPP was obtained as an off-white solid (0.64 g, 60\%). ${ }^{1} \mathrm{H}-\mathrm{NMR}(500 \mathrm{MHz}$, $\left.\mathrm{CD}_{3} \mathrm{OD}\right) \delta: 7.97-7.63(\mathrm{~m}, 18 \mathrm{H}), 7.51-7.48(\mathrm{~m}, 2 \mathrm{H}), 7.34(\mathrm{~d}, J=8.9$ $\mathrm{Hz}, 1 \mathrm{H}), 6.92(\mathrm{~d}, J=5.8 \mathrm{~Hz}, 1 \mathrm{H}), 6.83(\mathrm{~d}, J=8.8 \mathrm{~Hz}, 1 \mathrm{H}), 6.61$ $(\mathrm{s}, 1 \mathrm{H}), 5.82(\mathrm{~s}, 2 \mathrm{H}), 3.56(\mathrm{dd}, J=14.0,6.9 \mathrm{~Hz}, 8 \mathrm{H}), 3.37(\mathrm{t}, J=6.0$ $\mathrm{Hz}, 2 \mathrm{H}), 3.16-3.02(\mathrm{~m}, 10 \mathrm{H}), 2.78-2.69(\mathrm{~m}, 2 \mathrm{H}), 2.66-2.56(\mathrm{~m}$, $2 \mathrm{H}), 2.41(\mathrm{~m}, J=14.3,7.5 \mathrm{~Hz}, 2 \mathrm{H}), 2.38-2.30(\mathrm{~m}, 2 \mathrm{H}), 1.97-1.86$ $(\mathrm{m}, 2 \mathrm{H}), 1.81(\mathrm{dt}, J=11.9,5.8 \mathrm{~Hz}, 4 \mathrm{H})$, and $1.28(\mathrm{t}, J=6.9 \mathrm{~Hz}$, 6H); ${ }^{13} \mathrm{C}-\mathrm{NMR}$ (126 MHz, MeOD) $\delta: 170.38,169.08,160.98$, $158.43,155.27,153.49,149.43,145.03,144.88,136.52,134.86$, 134.78, 134.19, 131.76, 131.66, 131.59, 131.37, 129.43, 125.29, $125.05,123.53,119.63,119.03,118.94,115.95,111.12,108.72$, 108.64, 105.66, 97.97, 67.65, 50.82, 50.30, 45.87, 28.21, 22.97, 22.50, 22.17, and 12.82; $\mathrm{MS}\left(\mathrm{C}_{68} \mathrm{H}_{66} \mathrm{~N}_{5} \mathrm{O}_{5} \mathrm{P}^{2+}\right)$ : calculated $\left(\mathrm{MH}^{+}\right)$: 1063.4, found: 1066.1 .

Synthesis of ROX-coumarin (RC). To a solution of rhodamine 101 (ROX, $4.92 \mathrm{~g}, 10 \mathrm{mmol}$ ) in methanol $(20 \mathrm{ml})$ was added diethylenetriamine $(10.3 \mathrm{~g}, 100 \mathrm{mmol})$. The reaction mixture was maintained with stirring in an oil bath at $100{ }^{\circ} \mathrm{C}$ for $2 \mathrm{~h}$. After evaporation of methanol the residue was extracted with $\operatorname{DCM}(100 \mathrm{ml})$ and saturated aqueous $\mathrm{NaHCO}_{3}$ solution $(100 \mathrm{ml})$ twice. The combined organic phases were dried over anhydrous $\mathrm{Na}_{2} \mathrm{SO}_{4}$ and then concentrated to remove the solvent. The residue was purified by silica gel column chromatography using DCM/MeOH/TEA (20:1:1, v/v/v) as the eluent to give ROX-ETA as an off-white solid $(4.88 \mathrm{~g}, 85 \%) .{ }^{1} \mathrm{H}-\mathrm{NMR}\left(500 \mathrm{MHz}, \mathrm{CDCl}_{3}\right)$ $\delta: 7.91-7.86(1 \mathrm{H}, \mathrm{m}), 7.45-7.40(2 \mathrm{H}, \mathrm{m}), 7.07(1 \mathrm{H}, \mathrm{dt}, J=4.6$, $3.3 \mathrm{~Hz}), 5.98(2 \mathrm{H}, \mathrm{s}), 3.24(2 \mathrm{H}, \mathrm{t}, J=6.4 \mathrm{~Hz}), 3.15-3.11(4 \mathrm{H}, \mathrm{t})$, $3.10-3.06(4 \mathrm{H}, \mathrm{t}), 2.89(4 \mathrm{H}, \mathrm{dt}, J=10.0,4.8 \mathrm{~Hz}), 2.60(2 \mathrm{H}, \mathrm{t}, J=$ $5.9 \mathrm{~Hz}), 2.47(4 \mathrm{H}, \mathrm{dd}, J=11.1 \mathrm{HZ}, 6.1 \mathrm{~Hz}), 2.41(4 \mathrm{H}, \mathrm{t}, J=6.1$ $\mathrm{Hz}), 2.06-1.99(4 \mathrm{H}, \mathrm{m})$, and $1.88-1.82(4 \mathrm{H}, \mathrm{m}) ;{ }^{13} \mathrm{C}-\mathrm{NMR}$ 
$\left(126 \mathrm{MHz}, \mathrm{CDCl}_{3}\right) \delta: 168.81,154.03,148.39,143.69,132.47$, 131.23, 127.96, 124.73, 124.09, 122.75, 117.41, 107.80, 105.79, $65.90,52.19,50.04,49.60,47.97,41.94,40.45,27.30,22.14$, 21.62, and 21.35 (Scheme 2).

To a solution of 7-diethylamino-4-carboxy-coumarin $(2.61 \mathrm{~g}$, $10.00 \mathrm{mmol})$ in anhydrous DCM $(40 \mathrm{ml})$ was added $N$-hydroxysuccinimide (NHS, $1.73 \mathrm{~g}, 15.0 \mathrm{mmol}$ ) and 1-(3-dimethylaminopropyl)-3-ethylcarbodiimide hydrochloride (2.9 g, $15.0 \mathrm{mmol})$. The mixture was maintained at RT for $2 \mathrm{~h}$ with stirring. After removal of the solvent, the residue was purified by silica gel column chromatography using DCM as the eluent to yield the NHS ester of 7-diethylamino-coumarin-3-acid as a pale yellow solid (1.88 g, 50\%).

To a solution of ROX-ETA $(2.4 \mathrm{~g}, 4.2 \mathrm{mmol})$ in anhydrous dichloromethane was added the NHS ester of 7-diethylaminocoumarin-carboxylic acid $(1.8 \mathrm{~g}, 5 \mathrm{mmol})$ with TEA $(1 \mathrm{ml})$. The reaction mixture was stirred at room temperature for $12 \mathrm{~h}$. After rotary evaporation of the solvent, the residue was purified by silica gel flash column chromatography using DCM/PE/TEA (20:20:1, v/v/v) as the eluent to give RC as a pale gray solid (2.4 g, 70\%). ${ }^{1} \mathrm{H}-\mathrm{NMR}\left(500 \mathrm{MHz}, \mathrm{CDCl}_{3}\right) \delta: 8.81(\mathrm{t}, J=5.3 \mathrm{~Hz}$, $1 \mathrm{H}), 8.64(\mathrm{~s}, 1 \mathrm{H}), 7.86(\mathrm{dd}, J=5.8,2.7 \mathrm{~Hz}, 1 \mathrm{H}), 7.39(\mathrm{dd}, J=8.7$, $3.3 \mathrm{~Hz}, 3 \mathrm{H}$ ), 7.05 (dd, $J=5.7,2.6 \mathrm{~Hz}, 1 \mathrm{H}), 6.62(\mathrm{dd}, J=8.9$, $2.3 \mathrm{~Hz}, 1 \mathrm{H}), 6.47$ (d, $J=2.1 \mathrm{~Hz}, 1 \mathrm{H}), 5.99$ (s, 2H), 3.43 (q, $J=7.1$ $\mathrm{Hz}, 2 \mathrm{H}), 3.36(\mathrm{dd}, J=12.2,6.2 \mathrm{~Hz}, 4 \mathrm{H}), 3.23(\mathrm{t}, J=6.5 \mathrm{~Hz}, 2 \mathrm{H})$, $3.11(\mathrm{~d}, J=6.4 \mathrm{~Hz}, 2 \mathrm{H}), 3.06(\mathrm{dt}, J=16.3,5.5 \mathrm{~Hz}, 4 \mathrm{H}), 2.93-2.84$ $(\mathrm{m}, 4 \mathrm{H}), 2.60(\mathrm{t}, J=6.4 \mathrm{~Hz}, 2 \mathrm{H}), 2.55-2.40(\mathrm{~m}, 6 \mathrm{H}), 2.02(\mathrm{td}, J=$ $12.2,6.3 \mathrm{~Hz}, 4 \mathrm{H}), 1.89-1.80(\mathrm{td}, 4 \mathrm{H})$, and $1.22(\mathrm{t}, J=7.1 \mathrm{~Hz}, 6 \mathrm{H})$. ${ }^{13} \mathrm{C}-\mathrm{NMR}\left(126 \mathrm{MHz}, \mathrm{CDCl}_{3}\right) \delta: 168.62,163.30,162.63,157.70$, 154.03, 152.52, 148.34, 148.01, 143.66, 132.33, 131.25, 131.15, $127.83,124.69,124.01,122.73,117.39,110.59,109.92,108.45$, 107.76, 105.72, 96.67, 77.36, 65.84, 50.00, 49.55, 48.44, 47.79, $45.15,40.24,39.77,27.25,22.11,21.59,21.30$, and 12.52 .

pH titration of RC-TPP. Aliquots of the stock solution of RC-TPP in DMSO were added to Britton-Robinson buffer (containing $10 \%$ DMSO) of various $\mathrm{pH}$ values $(4.5,4.71,4.8,5.0$, 5.19, 5.30, 5.40, 5.50, 5.64, 5.80, 5.91, 6.09, 6.17, 6.22, 6.59, 6.90, $7.50,8.00,8.50$, and 9.00$)$ to a final concentration of $20 \mu \mathrm{M}$. The fluorescence emission spectra were recorded as a function of pH using $\lambda_{\text {ex@425 nm }}$ for coumarin and $\lambda_{\text {ex@585 nm }}$ for rhodamine.

Staining of lysosomes and mitochondria in live cells. HeLa and L929 cells were cultured in DMEM spiked with Lysotracker green $(2 \mu \mathrm{M})$ or Mitotracker green $(1 \mu \mathrm{M})$ and RC-TPP $(1 \mu \mathrm{M})$ for $30 \mathrm{~min}$, washed with cold PBS, and then maintained in fresh DMEM for confocal fluorescence microscopic analysis.

Cellular distribution of RC-TPP and RC. HeLa cells were cultured in DMEM containing RC-TPP $(1 \mu \mathrm{M})$ or RC $(1 \mu \mathrm{M})$ for $30 \mathrm{~min}$, and then analyzed with a confocal fluorescence microscope.

Acidity mediated reversal staining of lysosomes. Tom20$\mathrm{GFP}^{+}$HeLa cells were cultured in DMEM spiked with RC-TPP $(3 \mu \mathrm{M})$ for $30 \mathrm{~min}$ and then further incubated in DMEM spiked with or without BFA ( $200 \mathrm{nM}$ ) for $1 \mathrm{~h}$. The cells were analyzed by confocal fluorescence microscopy.

Imaging of CCCP-mediated RC-TPP relocation. Tom20-GFP HeLa cells were incubated with RC-TPP $(2 \mu \mathrm{M})$ in the absence or presence of $\operatorname{CCCP}(0,10,100 \mu \mathrm{M})$ for $1 \mathrm{~h}$. The cells were analyzed by confocal fluorescence microscopy to pinpoint the locations of RC-TPP and Tom20-GFP.

Imaging of lysosome mediated fluorescence-on of RC-TPP. Tom 20-GFP ${ }^{+}$HeLa cells were cultured in DMEM supplemented with RC-TPP $(2 \mu \mathrm{M})$ for $30 \mathrm{~min}$ and then cultivated in DMEM spiked without or with CCCP $(20 \mu \mathrm{M})$ in the presence of BFA (200 nM) for $2 \mathrm{~h}$. The cells were analyzed by confocal fluorescence microscopy for GFP and RC-TPP fluorescence.

Flow cytometric analysis of CCCP induced activation of rhodamine fluorescence. HeLa cells stably expressing Tom 20-GFP were first cultivated in DMEM containing RC-TPP $(2 \mu \mathrm{M})$ for $30 \mathrm{~min}$, and then maintained in HBSS or DMEM spiked with or without CCCP for $4 \mathrm{~h}$. The cells were analyzed by flow cytometry for intracellular rhodamine fluorescence.

Cell death related fluorescence activation of RC-TPP. Tom20$\mathrm{GFP}^{+}$HeLa cells were cultured in DMEM containing RC-TPP $(2 \mu \mathrm{M})$ for $30 \mathrm{~min}$ and then further cultured for $4 \mathrm{~h}$ without or

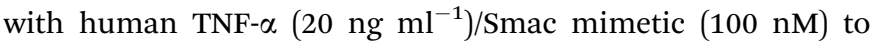
initiate apoptosis. At fixed time points, a portion of cells were analyzed by confocal fluorescence microscopy.

$\mathrm{RIP}^{+} /$Tom $20-\mathrm{GFP}^{+}$HeLa cells prestained with RC-TPP ( $2 \mu \mathrm{M}, 30 \mathrm{~min}$ ) were cultured for $6 \mathrm{~h}$ in DMEM containing no addition or human TNF- $\alpha\left(20 \mathrm{ng} \mathrm{m}^{-1}\right) / \mathrm{Smac}$ mimetic $(100 \mathrm{nM}) /$ $\mathrm{Z}-\mathrm{VAD}(20 \mu \mathrm{M})$ to initiate necroptosis. The cells were analyzed by confocal fluorescence microscopy.

Cytotoxicity of RC-TPP. HeLa cells were cultured with a medium containing RC-TPP $(0,1,2,5,10$, or $20 \mu \mathrm{M})$ for $30 \mathrm{~min}$ and washed with PBS 3 times then incubated with fresh medium for $6,12,24$, or $48 \mathrm{~h}$. The cell number and cell viability were determined by an MTT assay.

\section{Acknowledgements}

This work was supported by grants from NSF China (21572189, 21272196) and the Fundamental Research Funds for the Central Universities (20720160052, 20720150047), Xiamen University; Dr J. Han was supported by grants from NSF China (91429301, 31420103910, 31330047, 31221065), the National Scientific and Technological Major Project (2013ZX10002-002), the Hi-Tech Research and Development Program of China (863 program; 2012AA02A201), the 111 Project (B12001), the Science and Technology Foundation of Xiamen (3502Z20130027) and the National Science Foundation of China for Fostering Talents in Basic Research (J1310027). Boyu Han is thanked for assistance with the English in this paper.

\section{Notes and references}

1 (a) J. R. Friedman and J. Nunnari, Nature, 2014, 505, 335; (b) D. R. Green, Cell, 1998, 94, 695.

2 (a) M. T. Lin and M. F. Beal, Nature, 2006, 443, 787; (b) A. Abeliovich, Nature, 2010, 463, 744.

3 B. Chazotte, Cold Spring Harbor Protocols, 2011, 2011, 89.

4 (a) R. P. Haugland, Handbook of Fluorescent Probes and Research Chemicals, Molecular Probes, Inc., Eugene, Oregon, 1999; (b) S. Wu, Y. Song, Z. Li, J. Han and S. Han, Anal. Methods, 2014, 4, 1699; (c) M. H. Lee, N. Park, C. Yi, 
J. H. Han, J. H. Hong, K. P. Kim, D. H. Kang, J. L. Sessler, C. Kang and J. S. Kim, J. Am. Chem. Soc., 2014, 136, 14136.

5 B. Wang, X. Zhang, C. Wang, L. Chen, Y. Xiao and Y. Pang, Analyst, 2015, 140, 5488.

6 (a) W. Zhang, B. Tang, X. Liu, Y. Liu, K. Xu, J. Ma, L. Tong and G. Yang, Analyst, 2009, 134, 367; (b) T. Hasegawa, Y. Kondo, Y. Koizumi, T. Sugiyama, A. Takeda, S. Ito and F. Hamada, Bioorg. Med. Chem., 2009, 17, 6015.

7 (a) M. Yu, X. Wu, B. Lin, J. Han, L. Yang and S. Han, Anal. Chem., 2015, 87, 6688; (b) X. Wu, M. Yu, B. Lin, H. Xing, J. Han and S. Han, Chem. Sci., 2015, 6, 798; (c) Z. Li, S. Wu, J. Han and S. Han, Analyst, 2011, 136, 3698; (d) X. Wu, B. Lin, M. Yu, L. Yang, J. Han and S. Han, Chem. Sci., 2015, 6, 2002.

8 (a) J. Asin-Cayuela, A. R. Manas, A. M. James, R. A. Smith and M. P. Murphy, FEBS Lett., 2004, 571, 9; (b) H. Yuan, H. Cho, H. H. Chen, M. Panagia, D. E. Sosnovik and L. Josephson, Chem. Commun., 2013, 49, 10361; (c) M. F. Ross, G. F. Kelso, F. H. Blaikie, A. M. James, H. M. Cocheme, A. Filipovska, T. Da Ros, T. R. Hurd, R. A. Smith and M. P. Murphy, Biochemistry, 2005, 70, 222; (d) H. M. Cocheme, G. F. Kelso, A. M. James, M. F. Ross, J. Trnka, T. Mahendiran, J. Asin-Cayuela, F. H. Blaikie, A. R. Manas, C. M. Porteous, V. J. Adlam, R. A. Smith and M. P. Murphy, Mitochondrion, 2007, 7, S94; (e) S. E. AbuGosh, N. Kolvazon, B. Tirosh, I. Ringel and E. Yavin, Mol. Pharm., 2009, 6, 1138; (f) G. F. Kelso, C. M. Porteous, C. V. Coulter, G. Hughes, W. K. Porteous, E. C. Ledgerwood, R. A. Smith and M. P. Murphy, J. Biol. Chem., 2001, 276, 4588.

9 J. Llopis, J. M. McCaffery, A. Miyawaki, M. G. Farquhar and R. Y. Tsien, Proc. Natl. Acad. Sci. U. S. A., 1998, 95, 6803.

10 P. G. Heytler, Biochemistry, 1963, 2, 357.

11 T. Yoshimori, A. Yamamoto, Y. Moriyama, M. Futai and Y. Tashiro, J. Biol. Chem., 1991, 266, 17707.

12 X. Zhang, C. Wang, Z. Han and Y. Xiao, ACS Appl. Mater. Interfaces, 2014, 6, 21669.

13 M. Frank, S. Duvezin-Caubet, S. Koob, A. Occhipinti,

R. Jagasia, A. Petcherski, M. O. Ruonala, M. Priault,
B. Salin and A. S. Reichert, Biochim. Biophys. Acta, 2012, 1823, 2297.

14 A. Fleming, T. Noda, T. Yoshimori and D. C. Rubinsztein, Nat. Chem. Biol., 2011, 7, 9.

15 (a) Y. Kabeya, N. Mizushima, T. Ueno, A. Yamamoto, T. Kirisako, T. Noda, E. Kominami, Y. Ohsumi and T. Yoshimori, EMBO J., 2000, 19, 5720; (b) N. Mizushima, T. Yoshimori and B. Levine, Cell, 2010, 140, 313.

16 H. Katayama, T. Kogure, N. Mizushima, T. Yoshimori and A. Miyawaki, Chem. Biol., 2011, 18, 1042.

17 S. Rodriguez-Enriquez, I. Kim, R. T. Currin and J. J. Lemasters, Autophagy, 2006, 2, 39.

18 (a) P. Boya and G. Kroemer, Oncogene, 2008, 27, 6434; (b) U. Repnik, M. Hafner Cesen and B. Turk, Mitochondrion, 2014, 19, 49.

19 T. Vanden Berghe, A. Linkermann, S. Jouan-Lanhouet, H. Walczak and P. Vandenabeele, Nat. Rev. Mol. Cell Biol., 2014, 15, 135.

20 S. He, L. Wang, L. Miao, T. Wang, F. Du, L. Zhao and X. Wang, Cell, 2009, 137, 1100.

21 (a) G. Kroemer and M. Jaattela, Nat. Rev. Cancer, 2005, 5, 886; (b) K. C. Vaughn, L. R. Debonte, K. G. Wilson and G. W. Schaffer, Science, 1980, 208, 196; (c) P. H. Reddy, P. Mao and M. Manczak, Brain Res. Rev., 2009, 61, 33; (d) A. Sawa, G. W. Wiegand, J. Cooper, R. L. Margolis, A. H. Sharp, J. F. Lawler Jr, J. T. Greenamyre, S. H. Snyder and C. A. Ross, Nat. Med., 1999, 5, 1194.

22 (a) Y. Chen, C. Zhu, Z. Yang, J. Chen, Y. He, Y. Jiao, W. He, L. Qiu, J. Cen and Z. Guo, Angew. Chem., Int. Ed. Engl., 2013, 52, 1688; (b) B. C. Dickinson and C. J. Chang, J. Am. Chem. Soc., 2008, 130, 9638; (c) Y. Koide, Y. Urano, S. Kenmoku, H. Kojima and T. Nagano, J. Am. Chem. Soc., 2007, 129, 10324; (d) L. Yuan, L. Wang, B. K. Agrawalla, S. J. Park, H. Zhu, B. Sivaraman, J. Peng, Q. H. Xu and Y. T. Chang, J. Am. Chem. Soc., 2015, 137, 5930; (e) C. Zhang, Q. Hu, G. Feng, R. Zhang, Y. Yuan, X. Lu and B. Liu, Chem. Sci., 2015, 4, 4580; (f) J. J. Zhou, L. Li, W. Shi, X. Gao, X. Li and H. Ma, Chem. Sci., 2015, 6, 4884.

23 C. Li and R. M. Evans, Nucleic Acids Res., 1997, 25, 4165. 